\title{
Luminescence dating of Quaternary sediments
}

\author{
Preusser, F. \& Schlüchter, C. \\ Institute of Geological Sciences, Bern University, 3012 Bern, Switzerland.preusser@geo.unibe.ch, \\ schluechter@geo.unibe.ch
}

Luminescence dating allows the determination of sediment deposition ages. It uses a light sensitive signal in quartz and feldspar grains that is zeroed by daylight during sediment transport and rises during burial, when the grains are sealed from sunlight (Aitken 1998). The luminescence signal is induced by naturally occurring radioactivity originating from the decay of ${ }^{40} \mathrm{~K}$ and nuclides from the ${ }^{232} \mathrm{Th}$ and ${ }^{238} \mathrm{U}$ decay chains. Ages are calculated by determining both the luminescence intensity as a measure of dose absorbed by the mineral grains (expressed as palaeodose) and the amount of radioactive elements in the sediment.

A major limitation in dating is a possible incomplete resetting of the luminescence signal prior to deposition. Under direct sunlight exposure, it takes a few minutes to zero the optically stimulated luminescence (OSL) signal. This time increases dramatically in aquatic environments due to the absorption of daylight by water column, turbulence, and turbidity. While aeolian sediments such as loess and dune sands are usually well bleached, it is necessary to investigate the amount of resetting in water-lain deposits. This is done by investigating the shape of OSL curves, the scatter in OSL results, and by the comparison of the results determined for luminescence signals having different bleaching characteristics (Wallinga 2002).

Under optimal circumstances, it may be possible to date sediments as young as a few decades as demonstrated for dune sands from Texel, The Netherlands (Ballarini et al. 2003). The upper dating limit is reached when no more latent OSL can be stored within the crystal lattice and depends on the luminescence properties of the minerals investigated and on the amount of radioactivity within the sediment. The oldest ages reported so far are from stranded beach-dunes of low radioactivity from Australia with ages of up to $800,000 \mathrm{yr}$ (Huntley et. al. 1993). However, in most sedimentary settings the upper dating limit may be much lower but it is usually possible to date back to at least the Last Interglacial (c. 130,000 yr).

In Switzerland, research has so far concentrated on using OSL for establishing a reliable chronology of the last glacial cycle. First OSL evidence indicates an ice advance from the Alps into the lowland just after the Last Interglacial during the equivalent of Marine Isotope Stage (MIS) 5d (c. 105,000 yr) (Preusser et al. 2003, Preusser and Schlüchter 2004). The extension of glaciers during this time was probably smaller than during the Last Glacial Maximum (LGM). OSL and U/Th ages from the Zell site indicate a relatively warm interstadial period at about 96,000 yr ago (Preusser et al. 2001). It is assumed that Alpine glaciers retreated back into the Alps during this time. A second ice advance has recently been identified at the Finsterhennen site (Seeland) and correlates with MIS 4 (Preusser et al., submitted). The last glaciation of northern foreland of the Swiss Alps occurred after about 30,000 yr ago and reached its maximum extension at around c. 21,000 yr ago according to radiocarbon and surface exposure dating (Schlüchter and Röthlisberger 1995, Ivy-Ochs et al. 2004). OSL dating at three different sites confirms this correlation of the LGM with MIS 2 (Preusser et al., submitted).

\section{References}

Aitken, M.J. 1998: An introduction to optical dating. 267 pp., Oxford University Press, New York.
Ballarini, M., Wallinga, J., Murray, A.S., van Heteren, S., Oost, A.P., Bos, A.J.J., van Eijk, C.W.E. 2003: Optical dating of young coastal dunes on a decadal time scale. Quaternary Science Reviews 22, 1011-1017.

Huntley, D.J., Hutton, J.T., Prescott, J.R. 1993: The stranded beachdune sequence of south-east South Australia: a test of thermoluminescence dating 0-800 ka. Quaternary Science Reviews 12, 1-20.

Ivy-Ochs, S., Schäfer, J., Kubik, P.W., Synal, H.-A., Schlüchter, Ch. 2004: Timing of deglaciation on the northern alpine foreland (Switzerland). Eclogae Geologicae Helvetiae 97 (in press).

Preusser, F., Müller, B.U., Schlüchter, Ch. 2001. Luminescence dating of sediments from the Luthern valley, central Switzerland, and implications for the chronology of the last glacial cycle. Quaternary Research 55, 215-222.

Preusser, F., Geyh, M.A., Schlüchter, Ch. 2003. Timing of Late Pleistocene climate change in lowland Switzerland. Quaternary Science Reviews 22, 1435-1445.

Preusser F., Schlüchter, Ch. 2004: Dates from an important early Late Pleistocene ice advance in the Aare Valley, Switzerland. Eclogae Geologicae Helvetiae 97, 000-000. (in press)

Preusser, F., Graf, H.R., Schlüchter, Ch. submitted: Luminescence dating of glaciofluvial sediments from Switzerland.

Schlüchter, Ch., Röthlisberger, Ch. 1995: 100.000 Jahre Gletschergeschichte. In Gletscher im ständigen Wandel, 47-63, vdf, Zürich. 
2nd Swiss Geoscience Meeting, Lausanne, 2004

Wallinga, J. 2002: Optically

of fluvial sediments: a review.

Boreas 31,303-322. 